\title{
Ten years of Bio-Based and Applied Economics: a story of successes, and more to come
}

\author{
Fabio G. Santeramo ${ }^{1}$, Meri Raggi ${ }^{2}$ \\ ${ }^{1}$ University of Foggia (Italy) \\ ${ }^{2}$ University of Bologna (Italy)
}

Bio-based and Applied Economics, the official journal of the Italian Association of Agricultural and Applied Economics, has been established in 2011: the Journal has constantly hosted high quality manuscripts, published by scholars aiming at contributing to the debate on topics that have been relevant for the Association.

In less than ten years BAE has become a wellestablished international journal, indexed in several scientific databases, such as Scopus and Emerging Sources Citation Index ${ }^{\text {tw }}$ of Web of Science. Across years, the Journal has repeatedly devoted attention to innovative aspects for the profession, with a special attention to the definition and evolution of the bioeconomy (Schmidt et al., 2012), lately as the "evolutionary process of transition from systems of mining nonrenewable resources to farming renewable ones" (Zilberman et al., 2013). The importance of bioeconomy is increasing more and more exactly because its objectives are converging towards those of the new paradigm of economic growth: the circular economy (Aguilar et al., 2018). As from the very first articles hosted in the opening and in subsequent issues, such as those authored by Viaggi (2012), Romano (2012) and Esposti (2012), among others. The large number of submissions that the Journal has attracted has allowed to publish research papers from many very traditional areas such as agri-food system analyses, demand and production economics (e.g. Sckokai and Varacca, 2012), price, trade and policy analyses (e.g. Matthews, 2013; Jafari et al., 2018; Santeramo and Cramon-Taubadel, 2016). In addition, the Journal has hosted several manuscripts analysing fields closely connected with the agricultural and applied economics, such as environmental economics, behavioural economics, political economy, development economics, health economics, or focused on important and timely topics such as changes in the agri-food systems and methodological challenges in analysing them (e.g. Heckelei et al. 2012; Donati et al., 2013; Scoppola, 2015). Such a broad range of topics has allowed the Journal to become an agora for the scientific debate, and such a prominent role is very much strengthened by the Open Access nature of the Journal that, coupled with absence of submission and publication fees, guarantee that manuscripts are accessible to all interested readers, without limitations of any kind.

After a decade of great achievements, the Board has launched several initiatives (Moro et al., 2019) such as, among others, words mention to the most impactful papers hosted in BAE and the recurrent recognition of one "Best Paper in BAE". The first edition of these awards has been in 2021. Starting from the next years a special mention will also be dedicated to the reviewers that have excelled in their (extremely valuable) reviewer activities. The support of competent reviewers has been one of the main resources on which the Journal has counted to become a very well-established field Journal.

BAE is not only a fast-growing Journal, but also a resilient, fast-changing environment. After a deep reorganization of the Board, composed by the two Editors in Chief, five Associate Editors, and the editorial assistant, and a major transition to a new online platform, BAE has just renewed its graphical aspect to provide more information to the readers, and emphasize the rigor and transparency of the double-blind peer review process, a mechanism that ensure the high quality of the manuscripts hosted in BAE. Furthermore, the Journal will host more articles, organized in four issues per year: a signal that the growth in quality is solid and promising. 
The best has yet to be described. Among the new initiatives we proudly announce, starting form the following issues, BAE will host a series of invited reviews aimed at synthesizing the topics debated in BAE as well as at emphasizing the status of the art of the Bioeconomy, a repeated tradition for the Journal (e.g. Romano, 2013; Viaggi, 2016; Sckokai, 2016). Following the debate on bioeconomy is of utmost importance, due to the vivid attention that the topic is receiving not only in Europe (Wessler et al., 2017; D’Adamo et al., 2020; Stegmann et al., 2020), but also in other continents (Asada and Stern, 2018; Zilberman et al., 2018).

Moreover, BAE aims at publishing invited reviews on behavioural and risk management in agri-food systems issues in agri-food systems, themes that have attracted several important submissions (e.g. Coletta et al., 2018; O'Donoghue et al., 2020; Giampietri et al., 2020 ) and are highly debated in top field journals (Howley, 2015; Vigani, and Kathage, 2019; Sok et al., 2021).

In order to follow the debate on vulnerability, resilience and systemic changes in the agri-food sector, greatly animated by Allouche (2011), Upton et al. (2016), Pingali and Sunder (2017) and Shobe (2020), the Journal will continue to dedicate attention to the systemic changes in the agro-food systems, and to the resilience of the agri-food systems, updating the debated that has been animated in BAE by several authors such as, among others, Sarris (2013), Alvarez and Arias (2015), Avanzini et al. (2018) and Romano et al. (2019).

The Board has also solicited reviews to synthesize the state of the literature devoted to speculating on policy and trade dynamics (e.g. Peterson et al., 2000; Petit, 2008; Sun and Reed, 2010; Pannell and Claassen, 2020), whose debate dates back to the first issues of BAE (e.g. Moschini et al., 2012; Dwyer, 2013), but has never ended (e.g. Carbone et al., 2015; Olper, 2016), and, indeed, has increased in prominence (e.g. De Maria, 2018; Macedo et al., 2019).

Last, but not least, the Journal will dedicate space to review the state of the art on the rural development and on nutrition and health issues, whose debate has deep roots in BAE and it is quite promising and vivid (e.g. Barreiro-Hurle et al., 2010; Irwin et al., 2010; Camaioni et al., 2013; Sckokai et al., 2014; Bertolini and Pagliacci, 2017; Cerroni et al., 2019; Frison and Clément, 2020).

The Board is proud of the journey that the Journal is facing and will continue to work to ensure that $\mathrm{BAE}$ will continue to be an independent and Open Access environment to debate and disseminate rigorous scientific findings, and authoritative critical views. As closing note, the Editors in Chief express their gratitude to the scientists who have made possible the ambitious project of Bio-based and Applied Economics to become a solid reality.

\section{REFERENCES}

1. Aguilar, A., Wohlgemuth, R., \& Twardowski, T. (2018). Perspectives on bioeconomy. New Biotechnology. 40(25), 181-184

2. Allouche, J. (2011). The sustainability and resilience of global water and food systems: Political analysis of the interplay between security, resource scarcity, political systems and global trade. Food Policy, 36, S3-S8.

3. Asada, R., \& Stern, T. (2018). Competitive bioeconomy? Comparing bio-based and non-bio-based primary sectors of the world. Ecological Economics, 149, 120-128.

4. Avanzini, M., Salvador, I., \& Gios, G. (2018). Climate change and variations in mountain pasture values in the central-eastern Italian Alps in the eighteenth and nineteenth centuries. Bio-based and Applied Economics, 7(2), 97-116.

5. Barreiro-Hurle, J., Gracia, A., \& De-Magistris, T. (2010). The effects of multiple health and nutrition labels on consumer food choices. Journal of Agricultural Economics, 61(2), 426-443.

6. Bertolini, P., \& Pagliacci, F. (2017). Quality of life and territorial imbalances. A focus on Italian inner and rural areas. Bio-based and Applied Economics, 6(2), 183-208.

7. Camaioni, B., Esposti, R., Lobianco, A., Pagliacci, F., \& Sotte, F. (2013). How rural is the EU RDP? An analysis through spatial fund allocation. Bio-based and Applied Economics, 2(3), 277-300.

8. Carbone, A., Henke, R., \& Pozzolo, A. (2015). Italian agri-food exports in the international arena. Biobased and Applied Economics, 4(1), 55-75.

9. Cerroni, S., Watson, V., \& Macdiarmid, J. I. (2019). Consumers' rationality and home-grown values for healthy and environmentally sustainable food. Biobased and Applied Economics, 8(2), 101-132.

10. Coletta, A., Giampietri, E., Santeramo, F. G., Severini, S., \& Trestini, S. (2018). A preliminary test on risk and ambiguity attitudes, and time preferences in decisions under uncertainty: towards a better explanation of participation in crop insurance schemes. Bio-based and Applied Economics, 7(3), 265-277.

11. D'Adamo, I., Falcone, P. M., \& Morone, P. (2020). A new socio-economic indicator to measure the performance of bioeconomy sectors in Europe. Ecological Economics, 176, 106724. 
12. DeMaria, F., Lubello, P., \& Drogué, S. (2018). Measuring the complexity of complying with phytosanitary standard: the case of French and Chilean fresh apples. Bio-based and Applied Economics Journal, 7(1050-2020-421), 39-58.

13. Donati, M., Bodini, D., Arfini, F., \& Zezza, A. (2013). An integrated PMP model to assess the development of agro-energy crops and the effect on water requirements. Bio-based and Applied Economics, 2(3), 301321.

14. Dwyer, J. (2013). Transformation for sustainable agriculture: what role for the second Pillar of CAP? Biobased and Applied Economics, 2(1), 29-47.

15. Esposti, R. (2012). Knowledge, technology and innovations for a bio-based economy: lessons from the past, challenges for the future. Bio-based and applied economics, 1(3), 235-268.

16. Frison, E., \& Clément, C. (2020). The potential of diversified agroecological systems to deliver healthy outcomes: Making the link between agriculture, food systems \& health. Food Policy, 96, 101851.

17. Giampietri, E., Yu, X., \& Trestini, S. (2020). The role of trust and perceived barriers on farmer's intention to adopt risk management tools. Bio-based and Applied Economics, 9(1), 1-24.

18. Heckelei, T., Britz, W., \& Zhang, Y. (2012). Positive mathematical programming approaches-recent developments in literature and applied modelling. Bio-based and Applied Economics Journal, 1(1050-2016-85729), 109-124.

19. Howley, P. (2015). The happy farmer: the effect of nonpecuniary benefits on behavior. American Journal of Agricultural Economics, 97(4), 1072-1086.

20. Irwin, E. G., Isserman, A. M., Kilkenny, M., \& Partridge, M. D. (2010). A century of research on rural development and regional issues. American Journal of Agricultural Economics, 92(2), 522-553.

21. Jafari, Y., Britz, W., \& Beckman, J. (2018). The impacts to food consumers of a Transatlantic Trade and Investment Partnership. Bio-based and Applied Economics, 7(2), 139-160.

22. Macedo, A., Rebelo, J., \& Gouveia, S. (2019). Export propensity and intensity in the wine industry: a fractional econometric approach. Bio-based and Applied Economics, 8(3), 261-277.

23. Matthews, A. (2013). Greening agricultural payments in the EU's Common Agricultural Policy. Bio-based and Applied Economics, 2(1), 1-27.

24. Minarelli, F., Raggi, M., \& Viaggi, D. (2015). Innovation in European food SMEs: determinants and links between types. Bio-based and Applied Economics, 4(1), 33-53.
25. Moro, D., Santeramo, G., \& Viaggi, D. (2019). The future of Bio-Based and Applied Economics. Biobbased and Applied Economics, 8(1), 1-2.

26. Moschini, G., Cui, J., \& Lapan, H. (2012). Economics of biofuels: an overview of policies, impacts and prospects. Bio-based and Applied Economics, 1(3), 269-296.

27. O’Donoghue, C., Hynes, S., Kilgarriff, P., Ryan, M., \& Tsakiridis, A. (2020). Assessing preferences for rural landscapes: An attribute based choice modelling approach. Bio-based and Applied Economics Journal, 9(1050-2021-221), 171-200.

28. Olper, A. (2016). The political economy of traderelated regulatory policy: environment and global value chain.

29. Pannell, D. J., \& Claassen, R. (2020). The roles of adoption and behavior change in agricultural policy. Applied Economic Perspectives and Policy, 42(1), 31-41.

30. Peterson, E. W. F., \& Valluru, S. R. K. (2000). Agricultural comparative advantage and government policy interventions. Journal of Agricultural Economics, 51(3), 371-387.

31. Petit, M. (2008). The Asymmetries of Globalization. European Review of Agricultural Economics, 35(1), 105-107.

32. Pingali, P., \& Sunder, N. (2017). Transitioning toward nutrition-sensitive food systems in developing countries. Annual Review of Resource Economics, 9, 439459.

33. Romano, D. (2012). The Bio-based Economy: A new development model. Bio-based and Applied Economics, 1(3), 231-233.

34. Romano, D. (2013). Between crisis and development: which role for the bio-economy (and bio-economists). Bio-based and Applied Economics, 2(3), 209211.

35. Romano, D., Stefani, G., Rocchi, B., \& Fiorillo, C. (2019). The impact of assistance on poverty and food security in a fragile and protracted-crisis context: the case of West Bank and Gaza Strip. Bio-based and Applied Economics, 8(1), 21-61.

36. Santeramo, F. G., \& von Cramon-Taubadel, S. (2016). On perishability and Vertical Price Transmission: empirical evidences from Italy. Bio-based and Applied Economics Journal, 5(1050-2018-3676), 199214.

37. Sarris, A. (2013). Food commodity price volatility and food insecurity. Bio-based and Applied Economics, 2(3), 213-236.

38. Schmidt, O., Padel, S., \& Levidow, L. (2012). The BioEconomy Concept and Knowledge Base in a Pub- 
lic Goods and Farmer Perspective. Bio-Based and Applied Economics, 1(1), 47-63.

39. Scoppola, M. (2015). Innovation, productivity and growth: towards sustainable agri-food production. Bio-based and Applied Economics, 4(3), 199201.

40. Scoppola, M. (2014). Feeding the Planet and Greening Agriculture: Challenges and opportunities for the bio-economy. Bio-based and Applied Economics, 3(3), 185.

41. Sckokai, P., \& Varacca, A. (2012). Product differentiation and brand competition in the Italian breakfast cereal market: a distance metric approach. Bio-based and Applied Economics, 1(3), 297-312.

42. Sckokai, P., Veneziani, M., Moro, D., \& Castellari, E. (2014). Consumer willingness to pay for food safety: the case of mycotoxins in milk. Bio-based and Applied Economics, 3(1), 63-81.

43. Sckokai, P. (2016). The changing role of regulation in the bio-based economy: an introduction. Bio-based and Applied Economics, 5(3), 215-216.

44. Shobe, W. (2020). Emerging Issues in Decentralized Resource Governance: Environmental Federalism, Spillovers, and Linked Socio-Ecological Systems. Annual Review of Resource Economics, 12, 259279.

45. Sok, J., Borges, J. R., Schmidt, P., \& Ajzen, I. (2021). Farmer behaviour as reasoned action: a critical review of research with the theory of planned behaviour. Journal of Agricultural Economics, 72(2), 388412.

46. Stegmann, P., Londo, M., \& Junginger, M. (2020). The circular bioeconomy: Its elements and role in European bioeconomy clusters. Resources, Conservation \& Recycling: X, 6, 100029.

47. Sun, L., \& Reed, M. R. (2010). Impacts of free trade agreements on agricultural trade creation and trade diversion. American Journal of Agricultural Economics, 92(5), 1351-1363.

48. Upton, J. B., Cissé, J. D., \& Barrett, C. B. (2016). Food security as resilience: Reconciling definition and measurement. Agricultural economics, 47(S1), 135147.

49. Viaggi, D. (2016). Towards an economics of the bioeconomy: Four years later. Bio-based and Applied Economics, 5(2), 101-112.

50. Viaggi, D., Mantino, F., Mazzocchi, M., Moro, D., \& Stefani, G. (2012). From Agricultural to Bio-based Economics? Context, State of the Art and Challenges. Bio-Based and Applied Economics, 1(1), 3-11

51. Vigani, M., \& Kathage, J. (2019). To risk or not to risk? Risk management and farm productivity. Amer- ican Journal of Agricultural Economics, 101(5), 1432-1454.

52. Wesseler, J., \& von Braun, J. (2017). Measuring the bioeconomy: Economics and policies. Annual Review of Resource Economics, 9, 275-298

53. Zilberman, D., Kim, E., Kirschner, S., Kaplan, S., \& Reeves, J. (2013). Technology and the future bioeconomy. Agricultural Economics, 44(s1), 95-102.

54. Zilberman, D., Gordon, B., Hochman, G., \& Wesseler, J. (2018). Economics of sustainable development and the bioeconomy. Applied Economic Perspectives and Policy, 40(1), 22-37. 